Akreditasi KEMENRISTEKDIKTI, Nomor: 148/M/KPT/2020
http: / /jurnal.stkippersada.ac.id/jurnal/index.php/VOX

\title{
TEORI PSIKOSOSIAL ERIK ERIKSON: IMPLIKASINYA BAGI PENDIDIKAN AGAMA KRISTEN DI SEKOLAH
}

\author{
Valentino Reykliv Mokalu' ${ }^{1}$, \& Charis Vita Juniarty Boangmanalu \\ ${ }^{1,2}$ Program Pascasarjana Universitas Kristen Indonesia \\ Email:reyklivmokalu@gmail.com ${ }^{1}$, charisvjb@gmail.com2
}

INFO ARTIKEL
Riwayat Artikel:
$\begin{array}{ll}\text { Menerima } & : 06 \text { Agustus } 2021 \\ \text { Revisi } & : 09 \text { Agustus } 2021 \\ \text { Diterima } & : 08 \text { September } 2021\end{array}$

\section{Kata Kunci:}

Teori Psikososial, Erik Erikson, Pendidikan Agama Kristen, sekolah

\begin{abstract}
ABSTRAK
Teori Perkembangan Psikososial menurut Erik Erikson menjadi salah satu sumbangsih penting bagi dunia pendidikan, termasuk pendidikan agama Kristen. Delapan tahapan yang diutarakan oleh Erikson dapat dipastikan dilalui oleh setiap individu dalam perkembangan kehidupannya, meskipun tidak semua dapat melaluinya dengan sempurna. Sumbangsih teori ini bagi pendidikan agama Kristen menjadi pertimbangan penting, meskipun bukan satu-satunya teori perkembangan yang mesti dijadikan pertimbangan dalam penyelenggaraan pendidikan, khususnya pendidikan agama Kristen. Dalam artikel ini akan dijelaskan delapan tahapan perkembangan psikososial, tinjauan dan relevansinya bagi pendidikan agama Kristen yang ada di sekolah. Penelitian ini menggunakan metode penelitian studi kepustakaan (library research) yang di mana dilakukan pengumpulan data pustaka dengan membaca dan mengolah bahan menjadi sebuah penelitian. Hasil dan kesimpulannya, keberhasilan di tahap awal mempengaruhi peluang keberhasilan di tahap berikutnya. Dalam hal ini, peserta didik sendirilah yang mengembangkan keseimbangan tahapan demi tahapan. Dengan kata lain, hasil dari setiap tahapan mempengaruhi peluang hasil positif di tahapan berikutnya.
\end{abstract}

\section{Keywords: \\ Psychosocial Theory, Erik Erikson, Christian Religious Education, School}

Korespondensi:

Valentino Reykliv Mokalu

Universitas Kristen Indonesia Email:

reyklivmokalu@gmail.com

\begin{abstract}
Psychosocial development theory according to Erik Erikson is an important contribution in education sector including Christian religious education. The eight stages can certainly be passed by most individuals in their life's development. The contribution of this theory to Christian religious education is an important consideration, although this theory is not the only theory of development that must be taken into consideration in the provision of education. In this article, the eight stages of psychosocial development is explained, an overview, and the relevance for Christian religious education in schools. This study uses library research method where library data is collected by reading and processing the material. The result reports success in the early stages affecting the chances of success in later stages. In other words, the outcome of each stage affects the chances of a positive outcome in the next stage.
\end{abstract}

\section{PENDAHULUAN}

Perkembangan merupakan perubahan yang dapat dikatakan teratur, tersistemtis serta teroganisir dengan tujuan tertentu. Perkembangan memiliki ciri yang dapat diklasifikasikan yaitu: berkesinambungan, kumulatif, bergerak ke arah yang dapat dikatakan kompleks dan holistik. Tolok ukur bagi kita dalam melihat adanya perkembangan seseorang adalah pada aspek kemampuan yang dimiliki sesuai dengan tahap perkembangannya (Hidayati, 2017)

Perkembangan psikososial dari seseorang dapat ditinjau dari perspektif atau sudut pandang dari psikologi (Ahyani \& Astuti, 2018). Perkembangan dari masa anak-anak merupakan hal yang menarik untuk diteliti. Hubungan antara anak dengan keluarga, teman dan juga kehidupannya di sekolah (lingkungan) mempengaruhi perkembangan psikososial dari 
seorang anak (Hammer et al., 2016). Perkembangan sosial dari seorang anak akan meningkat karena ditandai dengan adanya perubahan pengetahuan serta pemahaman mereka tentang kebutuhan dan peraturanperaturan yang berlaku (Sita Dewi \& Yulaika, 2019)

Sangatlah penting bagi setiap manusia supaya dapat mengetahui bagaimana perkembangan psikososial dari anak terutama di era revolusi industri 4.0 yang memiliki tantangan yang berbeda dengan konteks kehidupan yang lalu. Teori Psikososial dari Erik Erikson menjadi bekal untuk mengoptimaklkan skill dari orang tua dan juga para guru untuk memahami dan dan mengerti untuk mendidik anak menuju taraf kedewasaan yang optimal dan cemerlang. Erik Erikson beranggapan bahwa sepanjang sejarah hidup manusia, setiap individu mengalami tahapan perkembangan dari bayi sampai dengan usia lanjut yang dinarasikan dalam teorinya yang terkenal yaitu teori psikososial.

Selain itu, Erik Erikson lebih melihat bahwa perkembangan manusia yang terjadi tidak dapat dilepaskan dari stimulus sosial yang dialaminya (Sudirjo \& Alif, 2018). Stimulus sosial merupakan penggerak dinamik dalam kepribadian seseorang. Penekanan Erikson pada stimulus sosial ini membedakannya dari tokoh psikoanalis lainnya (Mawarni Purnamasari \& Na'imah, 2020). Selain krisis psikososial yang dialami, Erikson juga menggambarkan perkembangan radius hubungan sosial yang mendasari krisis tersebut, beserta elemen dan modalitas sosial dari masing-masing tugas perkembangan (Maree, 2020).

Perkembangan setiap orang sepanjang hayat tersebut diperhadapkan dengan delapan tahapan yang masing-masing tahapan itu memiliki rintangannya untuk membentuk karakter setiap individu menjadi positif atau sebaliknya yang mendominasi pertumbuhan seseorang ("Pers. Healthc. Res.," 2017). Erikson menyebut setiap tahapan tersebut sebagai krisis atau konflik yang mempunyai sifat sosial dan psikologis yang sangat berdampak bagi kelangsungan perkembangan setiap individu di masa yang akan mendatang (Barzoki et al., 2015). Maka pengetahuan tentang psikososial anak akan membantu para orang tua bahkan pun guru yang ada disekolah dalam menghadapi tantangan saat mendidik anak-anak atau siswa supaya dapat mengoptimalkan proses perkembangan yang akan dialami anak dengan cara yang bersesuaian dengan yang dikehendaki/diinginkan.

\section{METODE PENELITIAN}

Penelitian ini menggunakan metode penelitian studi kepustakaan (library research) dimana dilakukan pengumpulan data pustaka dengan membaca dan mengolah bahan menjadi sebuah penelitian (Sari, 2020). Penulis juga membaca langsung pada teks dan bukan dengan pengetahuan langsung yang di dapat dari lapangan sehingga dapat juga disebut sumber sekunder yaitu di mana peneliti memperoleh data dari tangan kedua dan bukan data dari orsinil dari tangan pertama di lapangan dengan menggunakan penelitian kualitatif (Sugiyono, 2015). Penulisan ini mengangkat kemudian menganalisis tentang teori Erik Erikson yang dihubungkan dengan pendidikan agama Kristen di sekolah melalui teori yang ada sebelumnya.

\section{HASIL DAN PEMBAHASAN Biografi Erik Erikson}

Erik Erikson adalah salah seorang psikolog Jerman yang terkenal dengan teori tentang delapan tahap perkembangan pada manusia. Erikson menjadi terkenal karena upayanya dalam mengembangkan teori tentang tahap perkembangan manusia yang dirintis oleh Freud. Erikson menyatakan bahwa pertumbuhan manusia berjalan sesuai prinsip epigenetik yang menyatakan bahwa kepribadian manusia berjalan menurut delapan tahap (Schlein, 2016)

Berkembangnya manusia dari satu tahap ke tahap berikutnya ditentukan oleh keberhasilannya atau ketidakberhasilannya dalam menempuh tahap sebelumnya. Pembagian tahap-tahap ini berdasarkan periode tertentu dalam kehidupan manusia: bayi (0-3 tahun), balita (3-5 tahun), pra-sekolah (6-12 tahun), remaja (12-20 tahun), dewasa awal (2040 tahun), dewasa tengah (usia 40-65 tahun), dewasa lanjut (>65 tahun) (Honig, 2016). Masing-masing tahapan juga memiliki tugas perkembangan sendiri yang bersifat psikososial. Misalnya saja, pada usia bayi tujuan psikososialnya adalah menumbuhkan harapan dan kepercayaan. Kemudian bila tujuan ini tak tercapai, maka bayi itu akan lebih didominasi sifat penakut (Robert Pendergraft, 2017). 
Erikson lahir di Frankfurt, Jerman, pada 15 Juni 1902. Ayahnya adalah seorang kebangsaan Denmark yang tidak dikenal namanya dan ibunya, Karla Abrhamsen, adalah wanita Yahudi. Orang tuanya berpisah sebelum Erik lahir. Ibunya, Karla kemudian menikah dengan Dr. Theodore Homburger, lalu pindah ke Karlsruhe, Jerman Selatan (Winnicott, 2019).

Erikson menyelesaikan pendidikan di Gimnasium Pada usia 25 tahun. Beliau diundang untuk mengajar di sebuah sekolah swasta di Wina. Erikson menjadi begitu tertarik pada pendidikan anak-anak. Erikson akhirnya memilih kesenian, karena ia memiliki bakat dan minat di bidang itu. Pada masa hidupnya ini (Erikson pada waktu itu berusia 25 tahun) terjadilah sesuatu yang membuatnya berubah secara drastis. Ia diundang untuk mengajar pada suatu sekolah swasta kecil, di Wina. Sekolah ini dibangun sebagai tempat mendidik anak-anak, sementara mereka dan (atau) orang tua mereka menjalani psikoanalisis. Sekolah itu progresif dan para guru serta murid diberi kebebasan penuh dalam mengembangkan kurikulum.

Erikson menjadi begitu tertarik pada pendidikan anak-anak sehingga ia mengikuti dan tamat dari sekolah pendidikan guru yang menerapkan metode Montessori. Metode Montessori menekankan perkembangan inisiatif anak sendiri melalui permainan dan pekerjaan. Pengalaman ini memiliki pengaruh yang tidak pernah hilang dalam diri Erikson. Pengaruh lain yang lebih dalam ialah perkenalannya yang tak teralakan dengan psikoanalisis ialah ia berkenalan dengan perkumpulan Freud, mengikuti pendidikan beliau dengan konsep psikoanalisis di bawah bimbingan Anna Freud, mempelajari psikoloanalisis di Institut Psikoanalisis di Wina, dan tamat dari sana pada tahun 1933. Bisa dikatakan, ia telah menemukan identitas profesinya (Prihastiwi, 2019)

Singkatnya, Erikson belajar di lembaga pendidikan Psikoanalisis Sigmund Freud. Erikson mengambil konsentrasi pada bidang ilmu yang mempelajari masa anak-anak dan proses perkembangannya. Di sekolahnya itu, Erikson mengulas kembali serta mengembangkan teori Sigmund Freud (sering dikenal sebagai dengan istilah Psychosexual Theory) dan memberikan penekanan pada aspek "ego (psikologis)" sebagai komponen inti dari setiap manusia (Hasneli, 2019). Hal itulah yang menyebabkan Erik disebut sebagai "postfredian" Hasil dari pengembangan teori Freud yang dikerjakan oleh Erikson adalah Teori Psikosisal (Psychosocial Theory). Teori Erikson ini memiliki dampak yang penting terhadap bidang ilmu tahapan-tahapan perkembangan setiap individu. Hal ini disebabkan oleh karena Erikson mampu membuktikan bahwa perkembangan sebagai sesuatu yang berlangsung seumur hidup berdasarkan pengalamannya sendiri dan inilah yang disebut oleh Erikson sebagai Teori Psikososial itu sendiri (Pasiska \& Alisyahbana, 2020).

Erikson berkata bahwa orang-orang harus menemukan identitasnya dalam potensi-potensi masyarakatnya, sedangkan perkembangannya harus selaras dengan syarat-syarat yang dicanangkan masyarakat, atau mereka harus menanggung akibat-akibatnya. Sumbangan penting yang telah diberikan Erikson meliputi dua topik utama yaitu teori psikososial tentang perkembangan dari mana muncul suatu konsepsi yang luas tentang ego dan penelitian psikosejarah yang menerangkan psikososialnya (Maree, 2020)

\section{Teori Perkembangan Psikososial Erik Erikson}

Teori perkembangan psikososial Erikson menjelaskan perkembangan kepribadian manusia dalam beberapa tingkatan. Berikut ini dapat dilihat delapan tahapan perkembangan menurut teori psikososial Erikson:

\section{Stages of Psychosocial Development}

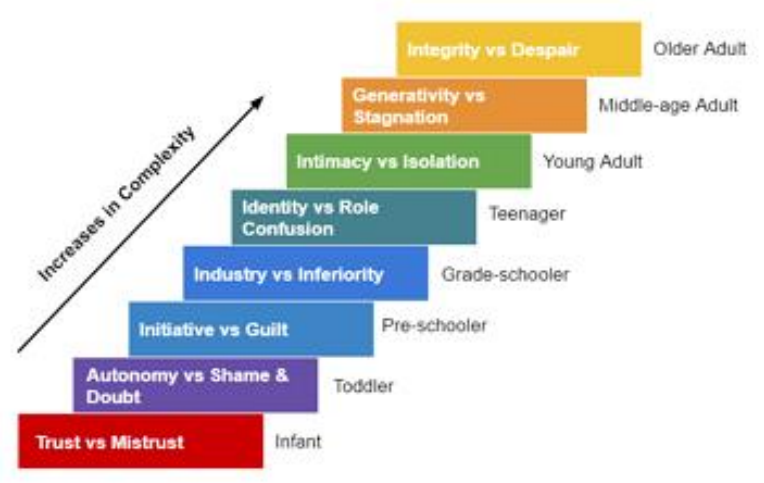

Gambar 1. Tahapan perkembangan berdasarkan Teori Psikososial 
Sumber: (Yahyu Herliany Yusuf et al., 2020)

\section{Trust versus Mistrust (sejak lahir hingga 1 tahun)}

Pada tahapan ini permulaan pembentukan kepribadian setiap individu. Rasa percaya tumbuh dari adanya perasaaan akan kenyamanan fisik dan rendahnya rasa ketakutan serta kecemasan tentang masa depan. Rasa percaya pada masa bayi membentuk harapan sepanjang hidup bahwa dunia adalah tempat yang baik dan menyenangkan untuk hidup ("Trust and Mistrust in International Relations," 2006).

Kepercayaan dasar yang paling awal terbentuk selama tahap sensorik oral dan ditunjukkan oleh bayi lewat kapasitasnya untuk tidur dengan tenang, menyantap makanan dengan nyaman dan membuang kotoran dengan santai. Kebiasaan itu berlangsung terus dalam kehidupan bayi dan merupakan dasar paling awal bagi berkembangnya suatu perasaan identitas psikososial. Melalui pengalaman dengan orang dewasa, bayi belajar menggantungkan diri dan percaya pada mereka, tetapi mungkin yang lebih penting, ia mempercayai dirinya sendiri. Kepastian semacam itu harus mengungguli lawan negatif dari kepercayaan dasar yakni, kecurigaan dasar. Pengharapan merupakan kebajikan paling awal dan paling esensial yang melekat dalam hidup. Fondasi pengharapan pertama terletak pada hubungan dengan orang tua yang memberikan pengalaman-pengalaman seperti ketenangan, makanan dan kehangatan (Wiresti \& Na'imah, 2020).

Pada saat yang sama, ia mengembangkan kemampuan untuk membuang pengharapan yang dikecewakan dan menemukan pengharapan dalam tujuan dan kemungkinan pada masa mendatang. Menurut Erikson, pengharapan adalah keyakinan yang bersifat menetap akan kemungkinan dicapainya hasrathasrat kuat. Tahap pertama kehidupan ini merupakan tahap ritualisasi numinous yaitu, perasaan bayi akan kehadiran ibu, dalam hal ini pandangannya, pegangannya, sentuhannya, teteknya atau "pengakuan atas dirinya". Bentuk ritual numinous yang menyimpang dan terungkap dalam kehidupan dewasa berupa pemujaan terhadap pahlawan secara berlebihlebihan atau idolisme (Khaironi, 2018).

\section{Autonomy versus Shame and Doubt (usia 1-3 tahun)}

Tahapan ini adalah tahap kedua perekembangan individu yang ditandai oleh perkembangan kemandirian (Aristya \& Rahayu, 2018). Anak di usia ini akan memasuki tahap mengenal dunia eksternal, yang mana anak akan mencoba mengenali dunia sekitarnya dengan mulut, mata dan tangan yang ia punya. Pada masa ini sampai batas-batas tertentu anak sudah mulai bisa berdiri sendiri, mencoba untuk duduk, berjalan, bermain, minum dari botol sendiri tanpa ditolong oleh orang tuanya, meskipun seringkali timbul keragu-raguan bahkan meminta pertolongan dari orang tua atau pengasuhnya. Anak-anak pada tahap ini sudah menampilkan rasa kemandiriannya (Suryana, 2016) .

Kemandirian anak akan optimal dan berkembang jika mendapat dukungan atau dorongan dari orang tuanya terhadap usaha yang dilakukan oleh anak (Holis, 2007). Namun, sebaliknya jika orang tua dalam mengasuh anaknya bersikap salah, maka anak dalam perkembangannya akan mengalami sikap malu dan ragu-ragu. Sedikit malu dan ragu adalah hal yang mestinya dianggap wajar. Tanpa itu, anak akan berkembang pada tendensi maladiptif, Erikson menyebutnya dengan impulsiveness yang akan membuat anak melakukan sesuatu tanpa pertimbangan. Orang yang kompulsif akan merasa semua gampang dilakukan dan akan sempurna, sehingga banyak orang yang pemalu dan merasa ragu pada dirinya. Sedikit kesabaran dan toleransi dalam membantu anak akan membantu perkembangan anak (Khoramnia et al., 2020).

Orang tua dalam mengasuh anak pada usia ini tidak perlu mengobarkan keberanian anak dan tidak pula harus mematikannya. Dengan kata lain, keseimbanganlah yang diperlukan di sini. Ada sebuah pernyataan relevan yang seringkali menjadi teguran maupun nasihat bagi orang tua dalam mengasuh anaknya yakni "tegas namun toleran". Makna dalam kalimat tersebut ternyata benar adanya, karena dengan cara ini anak akan bisa mengembangkan sikap kontrol diri dan harga diri. Apabila anak tidak berhasil melewati fase ini, maka anak tidak akan memiliki inisiatif yang dibutuhkan pada tahap berikutnya dan akan mengalami hambatan terus-menerus pada tahap selanjutnya (Wiresti \& Na'imah, 2020). 


\section{Initiative versus Guilt (3-6 tahun)}

Masa ini sering disebut dengan masa pra sekolah (Preschool Age) yang ditandai dengan adanya kecenderungan initiative - guilty. Pada tahap ini, perkembangan anak ditandai dengan kemampuan prakarsa sesuai dengan tugas perkembangannya (Widiastuti, 2019). Tahap ketiga ini juga dikatakan sebagai masa bermain.

Tahap ini terjadi pada suatu periode tertentu saat anak menginjak usia 3 sampai 6 tahun, dan tugas yang harus diemban seorang anak pada masa ini ialah untuk belajar mempunyai gagasan (inisiatif) tanpa banyak terlalu melakukan kesalahan. Inisiatif yang dimaksud ialah respon positif pada tantangan-tantangan dalam kehidupan. Orangtua mengharapkan inisiatif yang ditimbulkan anak adalah ia mampu mengeluarkan idenya (Hidayat \& Nur, 2018)

Apa yang harus dilakukan orang tua saat anak berada dalam tahapan ini? Orang tua diwajibkan memberi dorongan dan semangat bagi anak dalam mengeksplorasi dirinya. Jika tidak, anak akan tidak mampu mengembangkan prakarsa akibat kritik yang justru mematahkan semangat anak dan hanya membuatnya selalu memiliki rasa bersalah.

\section{Industry versus Inferiority (usia 6-12 tahun)}

Tahap ini terjadi pada anak saat memasuki sekolah dasar. Inisiatif anak membawanya berhubungan dengan berbagai pengalaman yang baru. Ketika anak memasuki masa anak pertengahan dan akhir, mereka mengarahkan kekuatannya untuk menguasai pengetahuan dan keterampilan intelektual. Sebagai kelanjutan dari perkembangan tahap sebelumnya, pada masa ini anak sangat aktif mempelajari apa saja yang ada di lingkungannya. Anak memiliki perasaan bahwa ia mampu melakukan sesuatu sesuai dengan kemampuannya (Issawi \& Dauphin, 2017). Dorongan untuk mengetahui dan berbuat terhadap lingkungannya sangat besar, tetapi di pihak lain karena keterbatasanketerbatasan kemampuan dan pengetahuannya kadang-kadang dia menghadapi kesukaran, hambatan bahkan kegagalan. Oleh karena itu, hal penting yang harus diperhatikan para orang tua dalam tahap ini ialah adalah dengan mengembangkan kemampuan bekerja keras anak dan menghindari perasaan rasa rendah diri (Trianingsih, 2016).

Saat anak-anak berada tahapan ini, area sosialnya bertambah luas dari lingkungan keluarga sampai ke lingkungan sekolah, sehingga semua aspek memiliki peran, misalnya orang tua harus selalu mendorong, guru harus memberi perhatian, teman harus menerima kehadirannya, dan lain sebagainya. Apabila anak dalam usia ini tidak diperlakukan seperti anak yang tidak mempunyai kemampuan, maka perkembangan anak akan diisi dengan perasaan rasa rendah diri (perasaan tidak dapat berkompeten dan tidak produktif).

\section{Identity versus Confusion (usia 12-18 tahun)}

Di sini, anak sudah mulai menjadi remaja. Masa ini merupakan masa pencarian identitas. Pada masa ini individu diperhadapkan untuk menemukan eksistensi dirinya (biasa disebut dengan pencarian jati diri). Akan ada berbagai macam gangguan yang harus diatasi agar dapat mencapai identitasnya. Apabila seorang remaja dalam mencari jati dirinya bergaul dengan lingkungan yang baik maka akan tercipta identitas yang baik pula. Jika tidak, maka akan terjadi krisis identitas (Kitchens \& Abell, 2020).

Peran orang tua menjadi sangat vital dalam tahap perkembangan ini. Orang tua berperan dalam mengembangkan identitas diri remaja. Orang tua yang terlalu protektif, otoriter dan membatasi ruang gerak remaja akan berdampak pada remaja yang tidak akan mampu memaknai pribadinya secara utuh. Remaja akan mengalami kebingungan (confusion) untuk mencari pedoman atau acuan dalam menjalani masa remajanya (Solobutina, 2020).

\section{Intimacy versus Isolation (usia 19-40 tahun)}

Dalam tahap ini, seseorang memasuki fase dewasa muda. Setiap individu dalam tahap ini siap dan berusaha untuk menyatukan identitasnya dengan orang lain. Singkatnya, individu mulai belajar untuk bermasyarakat. Individu dalam tahapan ini tampil sebagai seseorang yang mencintai, memelihara persahabatan, dan pekerjaan, bahkan berbagi dengan orang lain (Sarang et al., 2019). Beberapa hal tersebut akan menentukan kepercayaan dan harga diri individu dalam lingkungan orang seusianya. Apa resiko yang dialami individu jika pada tahapan ini ia mengalami kegagalan dalam mengembangkan diri? Umumnya tiap individu akan mengalami tekanan yang membuatnya merasakan kehidupan yang terisolasi (Sarang et al., 2019). 


\section{Generativity versus Stagnation (usia 40-65 tahun)}

Di dalam terminologi Erikson, generasi ini memasuki tahapan semangat berbagi vs penyerapan diri dan stagnasi (Usia 40-65 tahun) atau disebut usia dewasa. Mereka yang berada pada tahap ini memiliki semangat untuk membantu generasi muda dalam mengembangkan dan menjalani hidup agar lebih berguna. Fakta seseorang sudah memiliki anak tidak menjamin dia memiliki semangat berbagi. Misalnya, orang tua harus melakukan lebih banyak hal dari pada hanya menghasilkan keturunan: mereka juga harus melindungi dan membimbing mereka. Ini artinya orang tua harus sering mengorbankan kebutuhankebutuhan diri mereka sendiri (Sarang et al., 2019).

Selain itu mereka yang berada pada tahapan ini harus mengatasi godaan untuk memuaskan diri sendiri yang hanya akan mengarah kepada stagnasi tidak produktif. Stagnasi adalah perasaan bahwa individu tidak berbuat apapun untuk membantu generasi muda. Apabila mereka dapat mengatasi konflik ini secara positif, mereka akan mengembangkan kemampuan untuk memperhatikan generasi muda (Nantais \& Stack, 2017).

Menurut Erikson, seseorang yang tidak memiliki keturunan dapat mengembangkan semangat berbagi dan perhatian mereka. Contohnya adalah para biarawati dan pastor yang mampu mengasuh anak rohani mereka, seperti orang lain mengaplikasikan kemampuan istimewa mereka di bidang lain. Dengan demikian, orang-orang yang seperti ini dapat mengajar dan menuntun generasi selanjutya "dengan membimbing anak orang lain atau membantu menciptakan dunia yang lebih baik bagi mereka." (Page, 2018)

\section{Integrity versus Despair (usia 65 tahun ke atas)}

Kaum lanjut usia dalam tahapan ini harus menghadapi serangkaian kehilangan fisik dan sosial. Mereka kehilangan kekuatan fisik, kesehatan, kehilangan pekerjaan sehingga pendapatan mereka sekarang bergantung kepada dana pensiun. Seiring berjalannya waktu, mereka mulai kehilangan pasangan, kerabat atau teman-teman satu per satu. Erikson menyadari bahwa banyak penyesuaian fisik maupun sosial yang harus dilakukan para lansia (Gilleard, 2020).
Selain itu, Erikson menyebutkan tahapan ini merupakan pergulatan integritas ego vs keputusasaan. Seiring dengan mendekatnya para lansia menghadapi kematian, mereka mengevaluasi apa yang telah mereka lakukan selama hidupnya. Proses ini mereka berkonfrontasi dengan rasa putus asa puncak perasaan bahwa hidup bukan seperti yang diinginkan dahulu, namun sekarang waktu sudah habis, dan tidak ada lagi kesempatan untuk mencoba gaya hidup alternatif (Bertrand, 2019)

Sebagian besar mereka yang berada pada tahap ini, tidak lagi memiliki kesabaran untuk berjuang dan mengalahkan orang lain seperti dahulu. Semakin para lansia menghadapi rasa putus asa, mereka akan semakin berusaha memahami mengenai integritas ego. Menurut Erikson integritas ego sangat sulit didefinisikan namun mencakup perasaan bahwa sebuah siklus hidup yang harus terjadi . Selain itu, Erikson menekankan pentingnya kutub positif dan kutub negatif krisis para lansia. Seringkali kita melihat keterbatasan fisik dan sosial mereka, menemukan fakta bahwa para lansia ini "useless" . Akan tetapi penilaian semacam ini sebagai saja yang valid, karena opini-opini demikian dibentuk hanya karena melihat perilaku eksternal mereka saja (Ejim, 2020).

Jika kita terlalu fokus terhadap fakta bahwa para lansia tidak lagi memiliki semangat muda yang sangat dijunjung tinggi, maka kita gagal memahami pergulatan batin mereka. Kita gagal melihat bahwa pribadi-pribadi ini sedang bergulat dengan pertanyaan penting manusia: Apakah setelah menghadapi kematian, hidupku sudah berharga? Apa yang membuat hidupku boleh disebut bermakna?. Pergulatan batin ini cenderung membuat para lansia seperti seorang filsuf, bergulat dengan diri sendiri untuk menumbuhkan kekuatan ego yang disebut kebijaksanaan. Dalam hal ini kebijaksanaan dapat diungkapkan dengan berbagai cara, namun selalu merefleksikan upaya yang penuh dengan pertimbangan dan pengharapan. Hal ini bertujuan untuk menemukan nilai dan makna hidup saat menghadapi kematian (Lane \& Munday, 2020). 


\begin{tabular}{|c|c|c|c|c|}
\hline $\begin{array}{l}\text { Stage And } \\
\text { Approximate } \\
\text { Age Range }\end{array}$ & $\begin{array}{c}\text { Psycho- } \\
\text { Social Aspect }\end{array}$ & $\begin{array}{l}\text { Psycho- } \\
\text { Social Crisis }\end{array}$ & Virtue & Major Development \\
\hline $\begin{array}{c}\text { I } \\
\text { Infacy } \\
0-1\end{array}$ & Oral-Sensory & $\begin{array}{ll}\text { Trust } & v s \\
\text { Mistrust } & \end{array}$ & Hope & $\begin{array}{l}\text { Relasi orangtua dan anak akan } \\
\text { memberikan fondasi kepercayaan. } \\
\text { Harapan adalah kepercayaan yang } \\
\text { mempertahankan apa yang bisa } \\
\text { kita capai yang dibutuhkan dan } \\
\text { diinginkan. }\end{array}$ \\
\hline $\begin{array}{c}\text { II } \\
\text { Early Childhood } \\
1-3\end{array}$ & $\begin{array}{l}\text { Anal- } \\
\text { Muscular }\end{array}$ & $\begin{array}{l}\text { Autonomy vs } \\
\text { Shame, } \\
\text { Doubt }\end{array}$ & Will & $\begin{array}{l}\text { Mempelajari pengendalian diri } \\
\text { membentuk perasaan yang bebas, } \\
\text { tetapi anak juga berkembang } \\
\text { menjadi merasa malu dan ragu - } \\
\text { ragu tentang kapasitasnya untuk } \\
\text { melakukannya sendiri. Kemauan } \\
\text { adalah kemampuan untuk bebas } \\
\text { memilih dan mengendalikan dan } \\
\text { menerapkan terhadap diri sendiri. }\end{array}$ \\
\hline $\begin{array}{l}\text { III } \\
\text { Play age } \\
\text { 3-6 }\end{array}$ & $\begin{array}{l}\text { Infantile } \\
\text { Genital, } \\
\text { Locomotor }\end{array}$ & $\begin{array}{l}\text { Intitiative vs } \\
\text { Guilty }\end{array}$ & Purpose & $\begin{array}{l}\text { Mobilitas dan rasa ingin tahu } \\
\text { mendorong perkembangan dalam } \\
\text { inisiatif untuk menguasai } \\
\text { lingkungan, tetapi perasaan } \\
\text { bersalah lebih bersikap agresif dan } \\
\text { berani mungkin muncul. Cita-cita } \\
\text { digambarkan sebagai kemampuan } \\
\text { untuk menentukan dan mengejar } \\
\text { tujuan dengan percaya diri tanpa } \\
\text { takut akan hukuman. }\end{array}$ \\
\hline
\end{tabular}




\section{Alasan Mengapa Teori Erikson adalah Teori Pentahapan: Sebuah Tinjauan}

Beberapa hal yang dapat sampaikan sebagai sebuah tinjauan mengapa teori psikososial Erikson dikatakan sebagai teori pentahapan:

1. Pentahapan mengacu pada pola tingkah laku yang kuantitatif berbeda. Teori pentahapan Erikson memberikan kita pemahaman yang baik tentang bagaimana tingkah laku secara kualitatif berbeda di titik yang berbeda-beda (Crain, 2015). Anak-anak di tahap dua terlihat sangat berbeda dari bayi yang berada di tahap satu karena jauh lebih mandiri (Crain, 2015). Perilaku disetiap tahapan memiliki keunikan yang berbeda di setiap pentahapan Erikson.

2. Pentahapan masalah-masalah umum. Dalam paparan teorinya, Erikson berjalan melampaui fokus Freud yang relatif spesifik pada zona tubuh dan melukiskan persoalan umum di tiap periodenya (Crain, 2015). Misalnya, di tahap pertama Erikson menunjukkan bukan hanya stimulasi zona Freud saja yang penting. Akan tetapi, juga mode umum pelaksanaan dan perkembangan rasa percaya terhadap pengasuhan seseorang. Dengan cara yang sama Erikson, di tiap tahapannya Erikson berusaha mengisolasi persoalan yang paling umum yang dihadapi individu di dunia sosial (Crain, 2015)).

3. Pentahapan urutan yang tetap. Semua teori pentahapan selalu berpedoman kepada urutan yang tetap, Erikson tanpa terkecuali. Menurut Erikson, setiap tahapan selalu hadir dalam bentuk tertentu di seluruh hidup manusia. Setiap ta (Crain, 2015)hapan ini dapat mencapai krisisnya sendiri di waktu dan tatanan tertentu. Klaim Erikson ini dilandasi pada asumsi bahwa urutan pentahapannya merupakan hasil dari kedewasaan biologis.

4. Pentahapan bersifat universal secara kultural. Erikson percaya bahwa pentahapannya dapat diterapkan di semua budaya. Kita telah mengetahui bagaimana pentahapan bersifat universal karena diatur lewat pendewasaan, namun kita masih bisa skeptis karena mengetahui budaya sangat beragam. Erikson juga menyadari luasnya perbedaan antarbudaya ini(Crain, 2015). Salah satu tujuan Erikson membuat tahapan ini adalah menunjukkan bagaimana budaya bisa menangani pentahapan berbeda menurut sistem nilai masing-masing. Contohnya, suku (Lakota) Indian Sioux memberikan anak mereka periode pengasuhan yang lama dan penuh kesabaran (Crain, 2015). Hal ini bertujuan untuk memampukan anak mempercayai orang lain dan menjadi murah hati. Di sisi lain, budaya Amerika memutuskan ketergantungan ini.

Jika dibandingkan budaya lain, sebagian besar orang tua konteks Amerika tidak ingin anak mereka terlalu bergantung karena mereka harus mandiri.(Crain, 2015). Independensi dan pergerakan bebas tampaknya menjadi bagian dari etos budaya Amerika sejak dulu sampai sekarang. Dalam hal ini, Erikson berpandangan bahwa semua budaya mengarahkan diri mereka kepada persoalan yang sama(Crain, 2015). Semua budaya berusaha menyediakan anak mereka dengan perhatian yang konsisten, mengatur keinginan mereka untuk melakukan apapun dengan cara mereka sendiri (Crain, 2015)

Tabel 2. Pentahapan Freud dan Erikson berdasarkan buku Theories of Development: Concepts and Applications

\begin{tabular}{|c|c|c|}
\hline Usia & $\begin{array}{l}\text { Tahapan oleh } \\
\text { Freud }\end{array}$ & $\begin{array}{l}\text { Tahapan oleh } \\
\text { Erikson }\end{array}$ \\
\hline $\begin{array}{c}0-1 \\
\text { tahun }\end{array}$ & Oral & $\begin{array}{c}\text { Kepercayaan vs } \\
\text { Ketidakpercayaan: } \\
\text { Harapan }\end{array}$ \\
\hline $\begin{array}{l}1-3 \\
\text { tahun }\end{array}$ & Anal & $\begin{array}{l}\text { Otonomi vs rasa } \\
\text { malu, keraguan: } \\
\text { kemauan }\end{array}$ \\
\hline $\begin{array}{l}3-6 \\
\text { tahun }\end{array}$ & Tahap falus & $\begin{array}{c}\text { Inisiatif vs } \\
\text { Perasaan bersalah: } \\
\text { Tujuan }\end{array}$ \\
\hline $\begin{array}{l}\text { 6-11 } \\
\text { tahun }\end{array}$ & Tahap latensi & $\begin{array}{l}\text { Industri vs } \\
\text { inferioritas: } \\
\text { Kompetensi }\end{array}$ \\
\hline Remaja & Genital & $\begin{array}{c}\text { Identitas vs } \\
\text { kebingungan } \\
\text { peran: kesetiaan }\end{array}$ \\
\hline $\begin{array}{l}\text { Dewasa } \\
\text { muda }\end{array}$ & & $\begin{array}{l}\text { Keintiman vs } \\
\text { isolasi: cinta }\end{array}$ \\
\hline Dewasa & & $\begin{array}{l}\text { Generativitas vs } \\
\text { penyerapan diri, } \\
\text { stagnasi }\end{array}$ \\
\hline $\begin{array}{l}\text { Usia } \\
\text { tua }\end{array}$ & & $\begin{array}{c}\text { Integritas ego vs } \\
\text { putus asa: } \\
\text { kebijaksanaan }\end{array}$ \\
\hline
\end{tabular}

Tabel 3. Penjelasan krisis dalam Pentahapan berdasarkan teori psikososial 


\begin{tabular}{|c|c|c|}
\hline$\underset{\mathrm{t}}{\text { Tingka }}$ & $\begin{array}{l}\text { Krisis/Tugas } \\
\text { Psikososial }\end{array}$ & Yang Terjadi \\
\hline 1 & $\begin{array}{c}\text { Kepercayaan vs } \\
\text { ketidakpercayaa } \\
\text { n }\end{array}$ & $\begin{array}{c}\text { Apabila kebutuhan } \\
\text { terpenuhi secara } \\
\text { baik, maka bayi } \\
\text { akan } \\
\text { mengembangkan } \\
\text { rasa kepercayaan } \\
\text { dasar }\end{array}$ \\
\hline 2 & $\begin{array}{l}\text { Otonomi vs rasa } \\
\text { malu/keraguan }\end{array}$ & $\begin{array}{c}\text { Balita yang belajar } \\
\text { untuk berlatih akan } \\
\text { dan melakukan } \\
\text { sesuatu sendiri, } \\
\text { atau mereka } \\
\text { meragukan } \\
\text { kemampuan diri } \\
\text { mereka sendiri. }\end{array}$ \\
\hline 3 & $\begin{array}{l}\text { Inisiatif vs } \\
\text { kesalahan }\end{array}$ & $\begin{array}{l}\text { Anak usia dini } \\
\text { belajar untuk } \\
\text { berinisitif memulai } \\
\text { tugas-tugas dan } \\
\text { melakukan } \\
\text { rencana-rencana, } \\
\text { atau mereka merasa } \\
\text { bersalah terkait } \\
\text { usaha untuk } \\
\text { menjadi mandiri. }\end{array}$ \\
\hline 4 & $\begin{array}{l}\text { Percaya diri vs } \\
\text { rendah diri }\end{array}$ & $\begin{array}{l}\text { Anak-anak belajar } \\
\text { tentang } \\
\text { kepercayaan diri } \\
\text { menerapkan diri } \\
\text { pada tugas, atau } \\
\text { mereka merasa } \\
\text { rendah diri. }\end{array}$ \\
\hline 5 & $\begin{array}{l}\text { Identitas vs } \\
\text { kebingungan }\end{array}$ & $\begin{array}{c}\text { Remaja bekerja } \\
\text { dalam } \\
\text { penyempurnaan } \\
\text { rasa diri dengan } \\
\text { menguji peran yang } \\
\text { kemudian } \\
\text { mengintegrasikann } \\
\text { ya untuk } \\
\text { membentuk suatu } \\
\text { identitas, atau } \\
\text { mereka akan } \\
\text { menjadi bingung } \\
\text { tentang siapa } \\
\text { mereka. }\end{array}$ \\
\hline 6 & $\begin{array}{l}\text { Kedekatan vs } \\
\text { pengasingan }\end{array}$ & $\begin{array}{c}\text { Dewasa muda } \\
\text { berjuang untuk } \\
\text { membentuk } \\
\text { hubungan dekat } \\
\text { dan untuk } \\
\text { memperoleh } \\
\text { kemampuan untuk } \\
\text { cinta yang intim, } \\
\text { atau mereka merasa } \\
\text { diasingkan secara } \\
\text { sosial. }\end{array}$ \\
\hline
\end{tabular}

\begin{tabular}{|c|c|c|}
\hline 7 & $\begin{array}{c}\text { Generativitas vs } \\
\text { stagnasi }\end{array}$ & $\begin{array}{c}\text { Pertengahan usia } \\
\text { menemukan rasa } \\
\text { berkontribusi untuk } \\
\text { dunia, biasanya } \\
\text { melalui keluarga } \\
\text { atau pekerjaan, atau } \\
\text { mereka mungkin } \\
\end{array}$ \\
& & merasa kekurangan \\
& & tujuan. \\
\hline 8 & Integritas vs & Ketika \\
& putus asa & merefleksikan \\
& & hidupnya, orang \\
& & dewasa yang lebih \\
& & tua mungkin \\
& & merasakan rasa \\
& & kepuasan atau \\
& & kegagalan. \\
\hline
\end{tabular}

Sumber: Psychology Notes

\section{Implikasi Teori Psikososial Erikson bagi Pendidikan Agama Kristen di Sekolah}

Berdasarkan tahapan perkembangan Erikson, kekuatan dan kelemahan karakter dalam tahapan yang dominan saling mempengaruhi dari tahap satu kepada tahap berikutnya. Manusia dapat menjadi dewasa melalui setiap proses perkembangan apabila berhasil mengoptimalkan sisi positif dari setiap krisis atau konflik melalui kemampuannya untuk mengubah diri sendiri yang dipengaruhi oleh berbagai perubahan internal maupun eksternal (Septikasari \& Frasandy, 2018).

Perkembangan ilmu pengetahuan dan teknologi abad ke-21 masa kini sangat cepat. Dalam hal ini pendidik maupun naradidik diharapkan mampu beradaptasi dengan kemajuan yang berkembang pesat masa kini. Pada kurikulum 2013 kemendikbud memberikan perubahan yang fokus terhadap keterampilan anak bangsa (Septikasari \& Frasandy, 2018). Oleh karena hal ini, sekolah sebagai lembaga pendidikan dituntut untuk memiliki keterampilan berpikir kreatif (creative thinking), berpikir kritis dan pemecahan masalah (critical thinking and problem solving), berkomunikasi (communication), dan berkolaborasi (collaboration) atau yang biasa disebut dengan 4C. Dengan demikian, 4C menuntut peran pendidik untuk mengembangkan keterampilan baik hard skill dan soft skill pada peserta didik dalam proses pembelajaran. Hal ini bertujuan untuk mempersiapkan peserta didik untuk terjun dalam bidang pekerjaan di masa depan (Septikasari \& Frasandy, 2018). 
Pada bagian ini akan dibahas manfaat dari teori psikososial yang dikembangkan oleh Erikson ini bagi tugas Pendidikan Agama Kristen di sekolah sebagai sarana pembelajaran. Berdasarkan tahapan perkembangan Erikson, kekuatan dan kelemahan karakter yang dominan saling mempengaruhi dari tahap satu kepada tahap berikutnya. Manusia dapat menjadi dewasa melalui setiap proses perkembangan apabila berhasil mengembangkan sisi positif dari setiap konflik melalui kemampuannya untuk mengubah diri sendiri yang dipengaruhi oleh berbagai perubahan intern maupun peran orang-orang bermakna (Krismawati, 2018). Melalui teori perkembangan Erikson, anak usia 3-5 tahun membutuhkan penguatan "inisiatif" dari orangtua yang sedapat mungkin menghindari kata "jangan lakukan ini" melainkan, memberi kesempatan anak agar menguji kemampuannya (Krismawati, 2018)

Dalam menguji kemampuan anak perlu memulai mengenal pendidikan formal baik di Play Group maupun Taman Kanak-kanak (relasi sosial). Pengenalan lingkungan sekolah dengan guru, teman dan suasana baru dapat mendorong pengembangan inisiatif bila anak mendapat dukungan (Krismawati, 2018). Bagi anak usia 6-12 tahun teori perkembangan Erikson dapat menjadi pedoman penyusunan kurikulum yang memotivasi anak untuk percaya dengan kemampuannya seperti penerapan metode Cara Belajar Siswa Aktif (CBSA)(Krismawati, 2018). Hal ini dapat memacu kerja aktif anak serta menumbuhkan kompetisi sehat dalam kelompoknya.

Dalam proses pembelajaran dapat menggunakan media teknologi seperti Kahoot, Quizizz, Nearpod yang memuat materi pembelajaran (kuis, debat, diskusi, story telling) (Nehru, 2020). Media ini bertujuan untuk menarik dan melatih naradidik untuk 4C (Critical Thinking, Creativity, Collaboration, Communication) dalam pembelajaran tatap muka maupun pembelajaran dalam jaringan. Kemudian, memberikan sarana dan prasarana bagi anak mengikuti aktivitas seperti Pramuka, kegiatan ekstrakulikuler dan sebagainya.

Selain itu, bagi anak usia 12-20 tahun teori ini dapat menjadi pedoman penyusunan kurikulum yang diarahkan untuk merangsang cara berpikir remaja dalam menghadapi perubahan dunia. Hal ini dapat dilakukan melalui metode diskusi, pola belajar paduan pedagodi dan andragogi, atau pembahasan materi yang aktual (Nehru, 2020). Kontribusi teori perkembangan psikososial Erik Erikson bagi pengembangan sekolah seperti yang sudah dijelaskan di atas, dapat diuraikan dalam bentuk tabel di bawah ini:

\begin{tabular}{|c|c|}
\hline Usia & Keterangann \\
\hline $\begin{array}{l}0-2 \text { tahun } \\
\text { (Trust vs } \\
\text { Mistrust) }\end{array}$ & $\begin{array}{l}\text { 1. Membangun relasi sosial } \\
\text { dan mengenal berbagai } \\
\text { macam aktivitas di Play } \\
\text { Grup }\end{array}$ \\
\hline $\begin{array}{l}3-5 \text { tahun } \\
\text { (Autonomy } \\
\text { vs Shame } \\
\text { and } \\
\text { Doubt) }\end{array}$ & $\begin{array}{l}\text { 1. Membangun relasi sosial } \\
\text { dan mengenal berbagai } \\
\text { aktivitas di Taman Kanak- } \\
\text { kanak (TK) } \\
\text { 2. Mengadakan panggung } \\
\text { boneka sebagai media } \\
\text { pengajaran }\end{array}$ \\
\hline $\begin{array}{l}\text { 6-12 tahun } \\
\text { (Initiative } \\
\text { versus } \\
\text { Guilt) }\end{array}$ & $\begin{array}{l}\text { 1. Membangun relasi sosial } \\
\text { dan mengenal berbagai } \\
\text { aktivitas di Sekolah Dasar } \\
\text { 2. Pedoman penyusunan } \\
\text { kurikulum metode Cara } \\
\text { Belajar Siswa Aktif (CBSA) } \\
\text { 3. PRAMUKA } \\
\text { 4. Quizizz, Kahoot, Story } \\
\text { Telling }\end{array}$ \\
\hline $\begin{array}{l}12-20 \\
\text { tahun } \\
\text { (Industry } \\
\text { versus } \\
\text { Inferiority) }\end{array}$ & $\begin{array}{l}\text { 1. Membangun relasi sosial } \\
\text { dan mengenal kegiatan di } \\
\text { Sekolah Menengah Pertama, } \\
\text { Sekolah Menengah Atas, } \\
\text { dan Perkuliahan } \\
\text { 2. Studi Sosial } \\
\text { 3. Wisata Rohani } \\
\text { 4. Berbagai Ekstrakulikuler } \\
\text { 5. Organisasi Siswa Intra } \\
\text { Sekolah (OSIS) } \\
\text { 6. Badan Eksekutif Mahasiswa }\end{array}$ \\
\hline
\end{tabular}

\section{SIMPULAN}

Berdasarkan uraian perkembangan teori Psikososial Erikson, keberhasilan di tahap awal mempengaruhi peluang keberhasilan di tahap berikutnya. Dalam hal ini, peserta didik sendirilah yang mengembangkan keseimbangan tahapan demi tahapan. Dengan kata lain, hasil dari setiap tahapan mempengaruhi peluang hasil positif di tahapan berikutnya. Kreativitas dan karakter anak yang baik dapat didukung dengan beberapa faktor sebagai berikut: memberikan rangsangan 
mental yang baik, menciptkan lingkungan yang kondusif, peran pendidik yang mengembangkan kreativitas dan pendidikan karakter berbasis Kristiani.

fasilitator yaitu orang tua, guru, dan masyarakat kiranya dapat memotivasi/mendorong anak tersebut menjelajahi dunia dengan penuh harapan dan antisipasi dan bersemangat untuk melihat hal baru dari suatu tindakan secara mandiri.

Pemberian ruang bagi anak untuk mengeksplorasi aktivitas yang dapat mengembangkan kreativitas sangatlah penting. Diharapkan dengan adanya pemberian ruang ini anak akan mampu berpikir kreatif, berpikir kritis dan memecahkan masalah, berkomunikasi, berkolaborasi dalam kehidupannya.

\section{DAFTAR RUJUKAN}

Ahyani, L. N., \& Astuti, R. D. (2018). Buku Ajar Psikologi Perkembangan Anak Dan Remaja. Universitas Muria Kudus.

Aristya, D. N., \& Rahayu, A. (2018). Hubungan Dukungan Sosial Dan Konsep Diri Dengan Penyesuaian Diri Remaja Kelas $X$ SMA Angkasa I Jakarta. Jurnal Humaniora.

Barzoki, M. H., Kontula, O., Mokhtariaraghi, H., Mahboubishariatpanahi, N., Depper, A., Howe, P. D., Perpiñá Phd, C., Roncero Phd, M., Natenshon, A. H., Kehler PHD, M., Atkinson PHD, M., Chrisler, J. C., Digiammarino, A., Flynn, M. A., Park, S. S. S., Morin, D. T., Stana, A., Rafique, R., Hunt, N., ... Valadez Martinez, L. J. (2015). Book Reviews. Journal Of Child And Family Studies.

Bertrand, R. (2019). La Teoría Del Desarrollo Psicosocial De Erik Erikson. Psicología $Y$ Mente.

Crain, W. (2015). Theories Of Development: Concepts And Applications. In Theories Of Development: Concepts And Applications. Https://Doi.Org/10.4324/9781315662473

Ejim, M. (2020). Integrity Versus Despair: Perceptions Of Aging Among African Americans In Late Life. In Proquest
Dissertations And Theses.

Gilleard, C. (2020). The Final Stage Of Human Development? Erikson's View Of Integrity And Old Age. International Journal Of Ageing And Later Life. Https://Doi.Org/10.3384/Ijal.16528670.1471

Hammer, L. B., Johnson, R. C., Crain, T. L., Bodner, T., Kossek, E. E., Davis, K. D., Kelly, E. L., Buxton, O. M., Karuntzos, G., Casey Chosewood, L., \& Berkman, L. (2016). Intervention Effects On Safety Compliance And Citizenship Behaviors: Evidence From The Work, Family, And Health Study. Journal of Applied Psychology.

Https://Doi.Org/10.1037/Ap10000047

Hasneli, H. (2019). KONSEP MANUSIA DAN MANUSIA BERAGAMA DALAM PANDANGAN PSIKOLOGI AGAMA. TAJDID : Jurnal Ilmu Keislaman Dan Ushuluddin.

Https://Doi.Org/10.15548/Tajdid.V16i1. 153

Hidayat, S., \& Nur, L. (2018). NILAI KARAKTER, BERPIKIR KRITIS DAN PSIKOMOTORIK ANAK USIA DINI. JIV. Https://Doi.Org/10.21009/Jiv.1301.4

Hidayati, A. (2017). MERANGSANG PERTUMBUHAN DAN PERKEMBANGAN ANAK DENGAN PEMBELAJARAN TEMATIK TERPADU. Sawwa: Jurnal Studi Gender. Https://Doi.Org/10.21580/Sa.V12i1.1473

Holis, A. (2007). Peranan Keluarga/Orang Tua Dan Sekolah Dalam Mengembangkan Kreativitas Anak Usia Dini. Jurnal Pendidikan Universitas Garut.

Honig, A. S. (2016). Reflections On Erik Erikson's Clinical Work. Psyccritiques. Https://Doi.Org/10.1037/A0040609

Issawi, S., \& Dauphin, B. (2017). Industry Versus Inferiority. In Encyclopedia of Personality And Individual Differences. Https://Doi.Org/10.1007/978-3-31928099-8_593-1 
Khaironi, M. (2018). Perkembangan Anak Usia Dini. Jurnal Golden Age. Https://Doi.Org/10.29408/Goldenage.V2i 01.739

Khoramnia, S., Bavafa, A., Jaberghaderi, N., Parvizifard, A., Foroughi, A., Ahmadi, M., \& Amiri, S. (2020). The Effectiveness Of Acceptance And Commitment Therapy For Social Anxiety Disorder: A Randomized Clinical Trial. Trends In Psychiatry And Psychotherapy. Https://Doi.Org/10.1590/2237-60892019-0003

Kitchens, R., \& Abell, S. (2020). Ego Identity Versus Role Confusion. In Encyclopedia of Personality And Individual Differences.

Https://Doi.Org/10.1007/978-3-31924612-3_581

Krismawati, Y. (2018). Teori Psikologi Perkembangan Erik H. Erikson Dan Manfaatnya Bagi Tugas Pendidikan Kristen Dewasa Ini. Kurios. Https://Doi.Org/10.30995/Kur.V2i1.20

Lane, T. D., \& Munday, C. C. (2020). Ego Integrity Versus Despair. In Encyclopedia Of Personality And Individual Differences.

Https://Doi.Org/10.1007/978-3-31924612-3_582

Maree, J. G. (2020). The Psychosocial Development Theory Of Erik Erikson: Critical Overview. Early Child Development And Care. Https://Doi.Org/10.1080/03004430.2020. 1845163

Mawarni Purnamasari, \& Na'imah, N. (2020). Peran Pendidik Dalam Konsep Psikologi Perkembangan Anak Usia Dini. Jurnal Pelita

PAUD. Https://Doi.Org/10.33222/Pelitapaud.V4i 2.990

Nantais, C., \& Stack, M. (2017). Generativity Versus Stagnation. In Encyclopedia Of Personality And Individual Differences. Https://Doi.Org/10.1007/978-3-31928099-8_589-1
Nehru, N. A. (2020). Belajar Dari Rumah Pada Masa Pandemi Covid-19 Dalam Perspektif Konsep Perkembangan Psikososial Erikson. Academia.Edu.

Page, K. (2018). Erik Erikson. In Psychology For Actors. Https://Doi.Org/10.4324/9781351130950 $-7$

Person-Centred Healthcare Research. (2017). In Person-Centred Healthcare Research. Https://Doi.Org/10.1002/9781119099635

Prihastiwi, W. J. (2019). Role Of Self Concept, Emotional Regulation, Empathy In Predicting Forgiveness In Teens Of Junior High School Students In Surabaya. Humanities And Social Sciences Reviews. Https://Doi.Org/10.18510/Hssr.2019.732 1

Robert Pendergraft. (2017). Erik Erikson And The Church: Corporate Worship That Sustains Through Crises. Philosophy Study. Https://Doi.Org/10.17265/21595313/2017.06.001

Sarang, S., Karnam, A., \& Shitole, R. (2019). To Investigate The Relationship Between Psychological Factors And Stress In Two Different Developmental Stages In Adults: A Cross Sectional Study. The Indian Journal Of Occupational Therapy. Https://Doi.Org/10.4103/Ijoth.Ijoth_8_19

Sari, M. (2020). Penelitian Kepustakaan (Library Research) Dalam Penelitian Pendidikan IPA. Natural Science: Jurnal Penelitian Bidang IPA Dan Pendidikan IPA.

Schlein, S. (2016). The Clinical Erik Erikson: A Psychoanalytic Method Of Engagement And Activation. In The Clinical Erik Erikson: A Psychoanalytic Method Of Engagement And Activation.

Septikasari, R., \& Frasandy, R. N. (2018). Keterampilan 4C Abad 21 Dalam Pembelajaran Pendidikan Dasar. Tarbiyah Al-Awlad.

Sita Dewi, N. L. D. A., \& Yulaika, A. (2019). ANALISIS FAKTOR YANG 
MEMPENGARUHI PERKEMBANGAN MOTORIK HALUS PADA ANAK USIA PRASEKOLAH DI TK RA DIPONEGORO DESA NGAJUM KABUPATEN MALANG. Jurnal Kesehatan Mesencephalon. Https://Doi.Org/10.36053/Mesencephalo n.V5i2.181

Solobutina, M. M. (2020). Ego Identity Of Intellectually Gifted And Sport Talented Individuals In Puberty And Adolescence. Education And Self Development. Https://Doi.Org/10.26907/Esd15.1.02

Sudirjo, E., \& Alif, M. N. (2018). Pertumbuhan Dan Perkembangan Motorik Konsep Perkembangan Dan Pertumbuhan Fisik Dan Gerak Manusia. In UPI Sumedang Press.

Sugiyono. (2015). Metode Penelitian Pendidikan Pendekatan Kuantitatif, Kualitatif, Dan R\&D. Alfabeta.

Suryana, D. (2016). Pendidikan Anak Usia Dini: Stimulasi \& Aspek Perkembangan Anak. Prenada Media.

Trianingsih, R. (2016). PENGANTAR PRAKTIK MENDIDIK ANAK USIA SEKOLAH DASAR. Al Ibtida: Jurnal Pendidikan Guru MI. Https://Doi.Org/10.24235/Al.Ibtida.Snj. V3i2.880

Trust And Mistrust In International Relations. (2006). Choice Reviews Online. Https://Doi.Org/10.5860/Choice.43-4920

Widiastuti, N. L. G. K. (2019). Model Layanan Pendidikan Bagi Anak Berkebutuhan Khusus Yang Mengalami Kecacatan Fisik. Jurnal Ilmiah Ilmu Sosial. Https://Doi.Org/10.23887/Jiis.V5i1.1878 0

Winnicott, D. W. (2019). Erik H. Erikson. In Psycho-Analytic Explorations. Https://Doi.Org/10.4324/9780429478932 $-59$

Wiresti, R. D., \& Na'imah, N. (2020). Aspek Perkembangan Anak: Urgensitas Ditinjau Dalam Paradigma Psikologi
Perkembangan Anak. Aulad: Journal On Early Childhood. Https://Doi.Org/10.31004/Aulad.V3i1.53

Yahyu Herliany Yusuf, O., Ode Abdul Salam Al Amin, L., \& YPIQ Baubau, S. (2020). TEORI PERKEMBANGAN SOSIAL/PSIKOSOSIAL ERIK HOMBERGER ERIKSON. In Idrus Qaimuddin. 